\title{
Phytoplankton dan Zooplankton Sebagai Pakan Alami di Kolam Pasca Tambang Batubara Loa Bahu Samarinda
}

\author{
Henny Pagoray ${ }^{1}$ dan Komsanah Sukarti ${ }^{2}$ \\ 1,2 Program Studi Akuakultur Fakultas Perikanan dan IImu Kelautan, \\ Universitas Mulawarman \\ ${ }^{1}$ Email : pagoray.henny@gmail.com
}

\begin{abstract}
Water quality, natural feed in the form of phytoplankton, and zooplankton were used as indicators of water fertility that affect the cultivation activity. The study aims to determine the quantity, quality of phytoplankton and zooplankton in post coal mining ponds. The research method was done by observing the water quality in situ and ex situ in the post-coal pond at Loa Bahu coal mining. Plankton sampling was taken in every 3 days for 10 timesand analyzed at laboratory to identify their species, calculate their abundance, diversity index, uniformity and dominance. The analysis shows that the number of phytoplankton was 3,039-3,379 indv / liter; zooplankton was 4,508-5,146 indv / liter. Phytoplankton dominated by Chlorophycea, which reflects the quality of clean water. Plankton diversity index was 2.718-2.684, including moderate category. Uniformity index of plankton was 0.8419-0.8618, including stable category. The results of water quality analysis such as temperature, dissolved oxygen, $\mathrm{pH}, \mathrm{NO}_{2}, \mathrm{H}_{2} \mathrm{~S}$ were still reasonable for cultivation while $\mathrm{NH}_{3}$ exceeds of the standard.

Keywords: Phytoplankton, Zooplankton, Natural Feeds, Water Quality, Post Coal Mining Pond
\end{abstract}

\begin{abstract}
ABSTRAK
Kualitas air, pakan alami berupa phytoplankton dan zooplankton digunakan sebagai indikator kesuburan perairan yang berpengaruh terhadap usaha budidaya. Penelitian bertujuan untuk mengetahui kuantitas, kualitas phytoplankton dan zooplankton di kolam pasca tambang batubara. Metode penelitian yaitu dengan pengamatan kualitas air secara in situ dan ex situ dilakukan di kolam pasca tambang batubara Loa Bahu. Pengambilan sampel plankton setiap 3 hari sekali selama 10 kali. Sampel plankton di bawa ke laboratorium untuk diidentifikasi jenisnya, dihitung kelimpahannya, indeks keanekaragaman, keseragaman dan dominansi. Hasil analisis menunjukkan menunjukkan bahwa jumlah phytoplankton 3.039-3.379 indv/liter, zooplankton 4508-5146 indv/liter. Phytoplankton didominasi oleh Chlorophycea yang mencerminkan kualitas air bersih. Indeks keanekaragaman plankton 2,718 - 2,684, termasuk kondisi sedang, Keseragaman 0, 8419-0, 8618, termasuk kategori stabil. Hasil analisis kualitas air seperi suhu, oksigen terlarut, $\mathrm{pH}$, $\mathrm{NO}_{2}, \mathrm{H}_{2} \mathrm{~S}$ masih layak untuk budidaya, sedangkan untuk $\mathrm{NH}_{3}$ melebihi standar.

Kata kunci: Phytoplankton, Zooplankton, Pakan Alami, Kualitas Air, Kolam Pasca Tambang Batubara
\end{abstract}

\section{Pendahuluan}

Kolam pasca tambang batubara merupakan media yang dapat digunakan untuk usaha budidaya. Budidaya yang dilakukan pada kolam pasca tambang batubara perlu perhatian, baik kualitas air maupun pakan alami (plankton) yang terdiri dari phytoplankton dan zooplankton. Phytoplankton dan zooplankton yang merupakan organisme renik yang hidup di perairan dan sangat dipengaruhi oleh arus, keberadaannya dapat digunakan sebagai indikator kesuburan suatu perairan. 
Menurut Komarawidjaja (2016) adanya kegiatan penambangan batubara, selain telah menciptakan kolam-kolam raksasa akibat galian tambang juga diperkirakan menimbulkan tekanan terhadap ekosistem lingkungan akibat adanya perubahan struktur batuan yang diikuti dengan perubahan kualitas fisika dan kimia tanah serta air di sekitarnya. Air asam tambang ini dapat mengikis tanah dan batuan yang berakibat pada larutnya berbagai logam seperti besi (Fe), cadmium (Cd), mangan (Mn), dan seng ( $\mathrm{Zn}$ ) (Marganingrum \& Noviardi, 2009).

Penelitian yang telah dilakukan sehubungan dengan usaha budidaya di kolam pasca tambang, yaitu logam berat $(\mathrm{Pb}, \mathrm{Cd}, \mathrm{Cu}$, dan $\mathrm{Mn}$ ) yang terdeteksi pada plankton (Wahyudi et al., 2010), (Pagoray et al., 2014). Penelitian yang dilakukan di kolam pasca tambanhg batubara bahwa yang sensitif terhadap nilai indeks keberlanjutan dimensi ekologi yaitu indeks keanekaragaman plankton, parameter fisik (kekeruhan) dan kimia $\left(\mathrm{pH}, \mathrm{H}_{2} \mathrm{~S}\right.$ dan $\mathrm{NH}_{3}$ ).

Hasil penelitian Pagoray et al., (2015) tentang keberadaan plankton pada kolam pasca tambang batubara, menunjukkan bahwa kuantitas plankton sangat rendah, kelimpahan dan nilai indeks keanekaragamannya juga sangat rendah hal ini mengindikasikan bahwa perairan tersebut kurang subur. Penelitian di lahan bekas penambangan batubara untuk budidaya ikan lokal dapat dikembangkan pada kolam-kolam bekas tambang batubara yang kualitas airnya telah dikelola sebelumnya (Maidie et al., 2010). Pagoray \& Ghitarina (2020) setelah dilakukan fitoremediasi terhadap kolam pasca tambang batubara hasilnya menunjukkan bahwa proses fitoremediasi mampu memperbaiki kualitas air.

Berdasarkan hal tersebut maka penelitian ini dilakukan untuk mengetahui phytoplankton dan zooplankton sebagai pakan alami di kolam tambang batubara yang sudah dilakukan proses fitoremediasi. Tujuan penelitian ini untuk mengindentifikasi kondisi kolam pasca tambang batubara dengan melihat kualitas dan kuantitas dari phytoplankton dan zooplankton.

\section{Metode Penelitian}

\section{Lokasi dan Waktu Penelitian}

Penelitian dilakukan di kolam pasca tambang batubara Loa Bahu Samarinda. Penelitian dilakukan selama 1 (satu) bulan, sejak bulan Mei-Juni 2019. Kualitas air dan plankton (phytoplankton dan zooplankton) dianalisis di Laboratorium Lingkungan Perairan Jurusan Budidaya Perairan Fakultas Perikanan dan IImu Kelautan Universitas Mulawarman, Samarinda Kalimantan Timur. 


\section{Alat dan Bahan Penelitian}

Alat yang digunakan pada penelitian ini yaitu: Thermometer, mikroskop, $\mathrm{pH}$ meter, DO meter, alat-alat untuk titrasi (pipet, gelas ukur), kamera, plankton net, water sampler, timbangan, botol flakon, freezer, kantong plastik, cold box. Bahan yang digunakan yaitu: $\mathrm{HNO}_{3}$, standar nitrit, brucine sulfat, sulfanilic acid, lodium Natrium thiosulfate, dan formalin untuk pengawet.

\section{Pengumpulan Data}

Pengamatan kualitas air dilakukan secara in situ dan ex situ. Pengambilan sampel dilakukan di dua stasiun yakni stasiun Po yang perairannya tidak ada tumbuhan airnya, dan stasiun $\mathrm{Pa}$ yang perairannya ada tumbuhan airnya (hydrilla dan eceng gondok). Pengambilan sampel plankton sebanyak 10 liter dan disaring menggunakan plankton net no.25, pengambilan sampel dilakukan setiap 3 hari sekali selama 10 kali. Sampel plankton dibawa ke laboratorium untuk diidentifikasi jenisnya, dihitung kelimpahannya, indeks keanekaragaman, keseragaman dan dominansi.

\section{Analisis Data}

Indeks Keanekaragaman Shannon Wiener ( $\left.\mathrm{H}^{\prime}\right)$

Keanekaragaman ditentukan dengan menggunakan teori informasi Shannon-Wiener (1947) dalam Odum (1993) sebagai berikut :

$$
\begin{array}{ll}
\mathrm{H}^{\prime}=-\sum \frac{N i}{N} \log \frac{n i}{N} \\
\mathrm{H}^{\prime} \quad=\text { Indeks keanekaragaman jenis } \\
\mathrm{ni} & =\text { Jumlah individu tiap jenis } \\
\mathrm{N} & =\text { Jumlah individu seluruh jenis }
\end{array}
$$

Kriteria dari indeks keanekaragaman biota adalah :

$\mathrm{H}^{\prime}<1$ : Keanekaragaman spesies kecil, komunitas tidak stabil

$H^{\prime}$ 1-3 : Keanekaragaman spesies sedang, komunitas moderat

$\mathrm{H}^{\prime}>3$ : Keanekaragaman spesies besar, komunitas stabil

Keseragaman/kemerataan

Untuk mengetahui keseragaman jenis yaitu penyebaran individu antar spesies yang berada dalam komunitas digunakan rumus yang dikemukakan oleh (Odum, 1993). Penggunaan nilai E ditinjau dari sudut pencemaran, didasarkan atas adanya kemampuan spesies tertentu yang telah mampu beradaptasi pada kondisi tingkat pencemar tertentu.

$$
\mathrm{E}=\frac{H^{\prime}}{\operatorname{In}(S)}
$$

$$
\begin{array}{ll}
\mathrm{E} & =\text { Indeks keseragaman jenis } \\
\mathrm{H}^{\prime} & =\text { Indeks Shannon } \\
\mathrm{S} & =\text { Jumlah spesies dalam komunitas }
\end{array}
$$


Kriteria indeks keseragaman berkisar antara 0-1, jika nilai $E$ mendekati 1 maka sebaran individu antar spesies relatif merata, jika nilai $\mathrm{E}$ mendekati 0 , maka sebaran individu antar spesies tidak merata.

$0,00<\mathrm{E} \leq 0,50$ : Komunitas berada pada kondisi tertekan

$0,50<\mathrm{E} \leq 0,75$ : Komunitas berada pada kondisi labil

$0,75<\mathrm{E} \leq 1,00$ : Komunitas berada pada kondisi stabil

Dominansi Jenis (Keragaman Simpson)

Untuk mengetahui adanya dominansi biota tertentu dalam suatu komunitas, digunakan indeks dominansi Simpson (Koesoebiono, 1987;Odum, 1993)

$$
\mathrm{D}=\Sigma \frac{(n i)^{2}}{N^{2}}
$$

D = Indeks dominansi

$\mathrm{ni}=$ Jumlah individu masing-masing spesies

$\mathrm{N} \quad=$ Jumlah total individu

Kriteria indeks dominansi berkisar antara 0-1, yakni:

D mendekati 1 : Terdapat spesies yang mendominasi spesies lainnya

D mendekati 0 : Tidak terdapat spesies yang mendominasi.

\section{Hasil dan Pembahasan}

Plankton dijadikan indikator biologi dalam penentuan kualitas perairan karena menempati berbagai tropik level mulai dari produsen, konsumen, parasit, saprofit, transformer dan dekomposer. Komunitas Plankton juga memiliki jumlah spesies yang beranekaragam dengan jumlah individu per spesies yang tinggi sehingga memudahkan dalam analisis kuantitatif, pengambilan sampel dan penanganan sampel sangat mudah, serta berbagai indeks biologis dapat diterapkan. Secara luas plankton dianggap sebagai salah satu organisme terpenting di dunia, karena menjadi pakan alami untuk kehidupan akuatik.

\section{Plankton (Phytoplankton dan Zooplankton)}

Berdasarkan hasil identifikasi plankton pada dua stasiun selama 10 hari pengamatan yang dilakukan setiap 3 hari sekali, didapatkan kisaran jumlah jenis plankton untuk stasiun Po sebanyak 18 jenis dan stasiun $\mathrm{Pa} 17$ jenis. Jenis phytoplankton terdiri atas 2 familia yakni Chlorophyceae (4 jenis) dan Cyanophyceae (2 jenis), sedangkan zooplankton terdiri atas 3 famili yakni Mastigopora (2 jenis), Rotatoria (10 jenis) dan Crustacean (1 jenis). Hasil analisis jumlah dan jenis plankton dapat dilihat pada Tabel 1. 
Tabel 1. Jumlah dan jenis plankton pada setiap stasiun pengamatan

\begin{tabular}{|c|c|c|c|c|c|}
\hline \multirow{2}{*}{$\begin{array}{c}\text { Plankton } \\
\text { Fitoplankton }\end{array}$} & \multirow[t]{2}{*}{ Spesies } & \multicolumn{2}{|c|}{$\sum$ pengamatan } & \multicolumn{2}{|c|}{$\begin{array}{c}\text { Rataan } \\
\sum \text { indvidu/literl } \\
\text { Pengamatan }\end{array}$} \\
\hline & & Stat. Po & Stat.Pa & Stat. $\mathbf{P a}$ & Stat.Po \\
\hline Chlorophyceae & Pediastrum biwae & 10 & 10 & 704 & 721 \\
\hline Chlorophyceae & Spirogyra setiformis & 7 & 9 & 396 & 393 \\
\hline Chlorophyceae & Staurastrum subsaltans & 10 & 10 & 777 & 746 \\
\hline Chlorophyceae & Ulothrix aequalis & 2 & 2 & 578 & 560 \\
\hline Cyanophyceae & Merismopodia convoluta & 10 & 10 & 609 & 619 \\
\hline Cyanophyceae & Spirulina albida & 1 & - & 315 & - \\
\hline$\sum$ Fitoplankton & 6 & & & 3379 & 3039 \\
\hline \multicolumn{6}{|l|}{ Zooplankton } \\
\hline Mastigophora & Peridinium bipes & 10 & 10 & 651 & 700 \\
\hline Mastigophora & Phacus undulatus & 3 & 4 & 280 & 175 \\
\hline Rotatoria & Brachionus angualaris & 10 & 10 & 620 & 735 \\
\hline Rotatoria & Brachionus falcatus & 10 & 10 & 620 & 707 \\
\hline Rotatoria & Brachionus forficula & 10 & 10 & 557 & 718 \\
\hline Rotatoria & Brachionus quadridentatus & 10 & 10 & 767 & 809 \\
\hline Rotatoria & Keratella quadrata & 1 & 1 & 105 & 210 \\
\hline Rotatoria & Lecane sverigis & 2 & 1 & 158 & 105 \\
\hline Rotatoria & Lepadella sp & 1 & - & 105 & \\
\hline Rotatoria & Monostyla arcuata & 1 & 1 & 105 & 210 \\
\hline Rotatoria & Philodina roseloa & 1 & 1 & 105 & 210 \\
\hline Rotatoria & Trichocerca birostris & - & 5 & - & 168 \\
\hline Crustaceae & Cyclops sp & 7 & 9 & 435 & 399 \\
\hline$\sum$ Zooplankton & 13 & & & 4508 & 5146 \\
\hline
\end{tabular}

Pada Tabel 1 terlihat bahwa jumlah fitoplanktonnya 3039-3379 ind/L dan jumlah zooplanktonnya 4508-5146 ind/L. Fitoplankton sebagai produsen primer dijadikan sebagai salah satu parameter tingkat kesuburan suatu perairan. Kelimpahan fitoplankton dalam suatu perairan memberikan dampak yang positif bagi produktivitas perairan, dimana komposisi dan kelimpahan tertentu dari fitoplankton pada suatu perairan sangat berperan sebagai makanan alami pada tropik level diatasnya, juga berperan sebagai penyedia oksigen dalam perairan. Dalam hal ini fitoplankton menjadi sumber makanan utama oleh jenis zooplankton yang ada. Beberapa zooplankton ada pada setiap pengamatan baik di stasiun $\mathrm{Po}$ maupun $\mathrm{Pa}$, tetapi ada juga yang ditemukan di stasiun $\mathrm{Pa}$ tetapi tidak ditemukan di stasiun Po. Hal ini menunjukkan bahwa keberadaan tumbuhan hydrilla maupun eceng gondok di stasiun pengamatan tersebut berpengaruh terhadap pertambahan jenis zooplankton. Semakin banyak dan beragam fitoplankton menyebabkan biota meningkat dengan tingkatan trofik yang lebih tinggi, sehingga produktifitas perairan juga akan meningkat. Fitoplankton sebagai produsen lebih banyak dari zooplankton sebagai konsumen mengindikasikan ekosistem perairan relatif stabil (Oktavia et al., 2015).

Fitotoplankton Chlorophyceae jenis Pediastrum biwae dan Staurastrum subsaltans ditemukan di stasiun Po dan Pa. Spirogyra setiformis ditemukan pada stasiun Pa pada setiap pengamatan sedangkan pada stasiun Po mulai ditemukan pada pengamatan hari ke $4 \mathrm{~s} / \mathrm{d}$ ke 10 . Spirogyra merupakan jenis alga hijau yang memiliki bentuk seperti benang silindris ditemukan di kolam pasca tambang yang airnya tenang. Ulothrix aequalis 
ditemukan hanya pada pengamatan ke 10 saja. Nemerow (1991) dalam Wijaya (2009) menjelaskan fitoplankton yang didominasi oleh Chlorophyceae mencerminkan kualitas airnya bersih (berkaitan dengan perairan yang tidak tercemar) yang menggambarkan proses mineralisasi berlangsung dengan baik dan kandungan oksigen normal. Hasil pengamatan perbandingan jumlah jenis fitoplankton dan zooplankton pada stasiun Po dan Pa dapat dilihat pada Gambar 1.

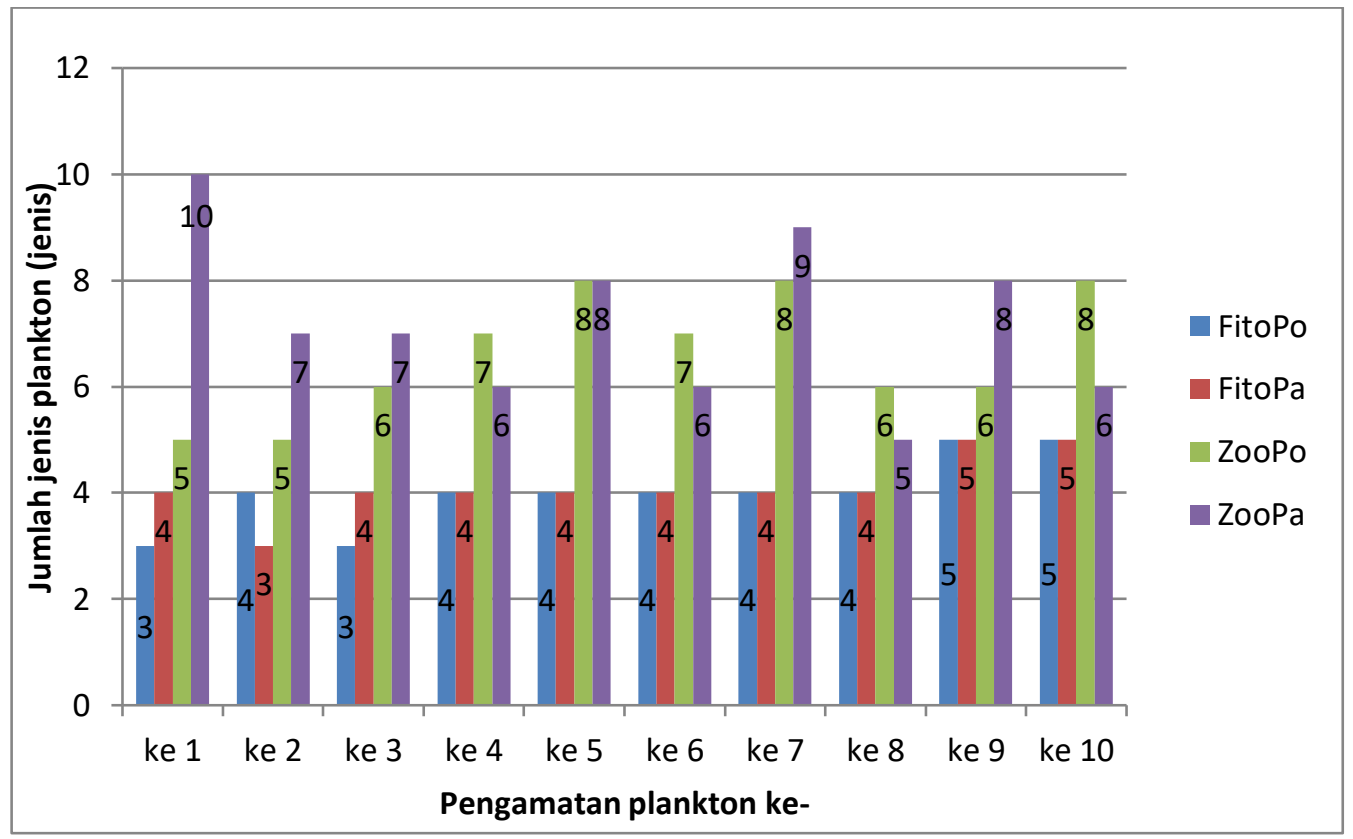

Gambar 1. Perbandingan Jumlah Jenis Fitoplankton dan Zooplankton Pada Stasiun Po dan Pa

Pada Gambar 1 terlihat perbandingan jumlah jenis fitoplankton dan zooplankton pada setiap stasiun. Jumlah jenis fitoplankton pada stasiun Po dan Pa sama fluktuasinya yakni antara $3 \mathrm{~s} / \mathrm{d} 5$ jenis. Jumlah jenis zooplankton pada stasiun $\mathrm{Pa}$ yang ada tumbuhan hydrilla dan eceng gondoknya antara $5 \mathrm{~s} / \mathrm{d} 10$ jenis lebih banyak dibandingkan dengan stasiun Po yang tidak ada tumbuhan airnya diperoleh jumlah jenis antara $5 \mathrm{~s} / \mathrm{d}$ 8. Untuk perbandingan jumlah individu/liter fitoplankton dan zooplankton dapat di lihat pada Gambar 2. 


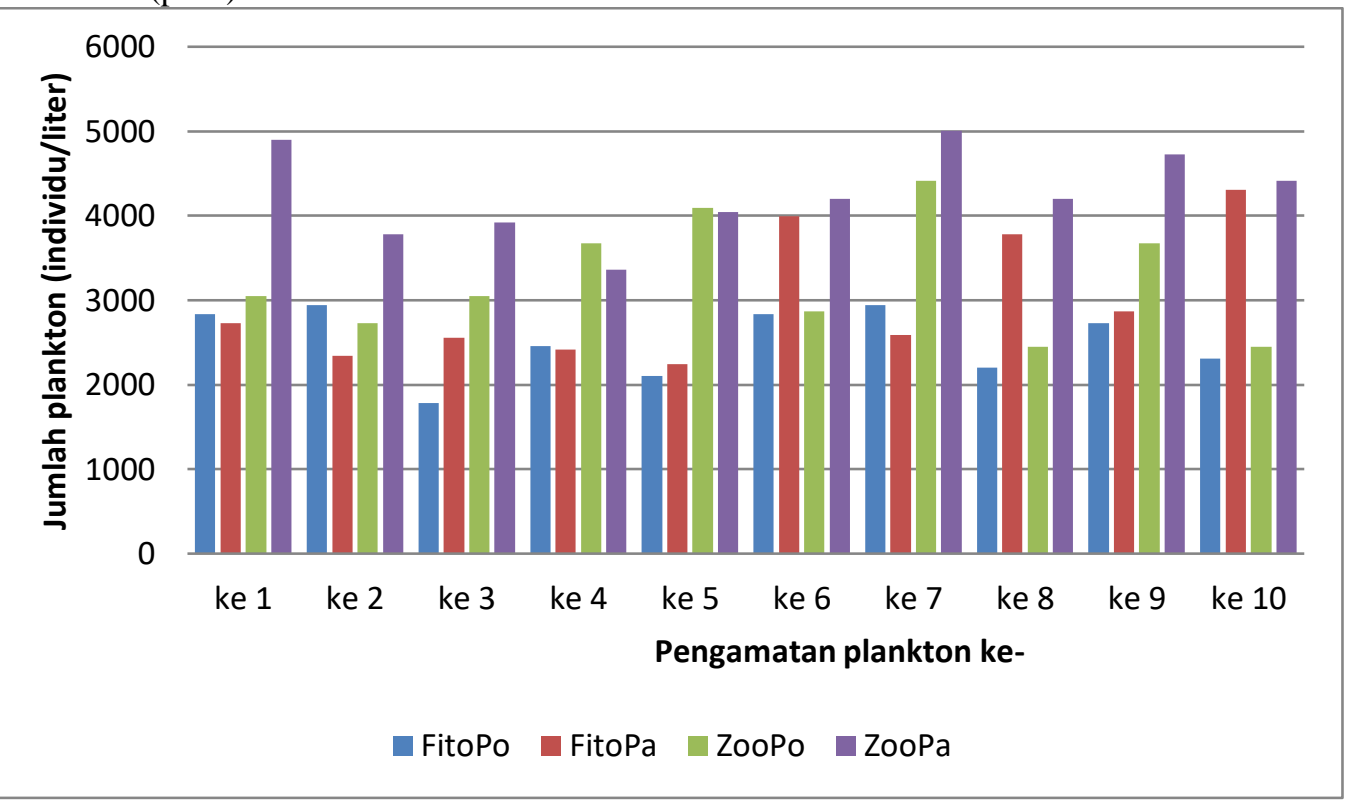

Gambar 2. Perbandingan jumlah individu/liter fitoplankton dan zooplankton pada stasiun $\mathrm{Po}$ dan $\mathrm{Pa}$

Pada Gambar 2, stasiun Pa jumlah fitoplanktonnya lebih banyak (individu/liter) dibanding stasiun Po, hal ini menunjukkan kolam pasca tambang yang ada tumbuhan airnya seperti hydrilla dan eceng gondok mempengaruhi jumlah plankton. Plankton (zooplankton dan fitoplankton) mempunyai peran yang sangat besar dalam ekosistem perairan, karena sebagai sumber makanan bagi hewan perairan lainnya. Zooplankton berperan dalam mengatur kelimpahan fitoplankton melalui selektifitas makanan (food selectivity), yaitu mekanisme yang signifikan untuk mengontrol komposisi dari komunitas fitoplankton. Oleh karena itu, zooplankton dapat dijadikan indikator kesuburan perairan, karena zooplankton berperan sebagai agen transfer energi dan indikator dari keberadaan fitoplankton. Hasil analisis plankton yaitu jumlah jenis, dominasi, keanekaraman dan keseragamab dapat dilihat pada Tabel 2.

Tabel 2. Indeks keanekaragaman plankton pada setiap stasiun pengamatan

\begin{tabular}{lcc}
\hline \multicolumn{1}{c}{ Kategori Analisis Data } & Stasiun Po & Stasiun Pa \\
\hline Taxa_S (Jumlah Jenis/kualitas) & 18 & 17 \\
Individuals (Jumlah individu/kuantitas) & 7887 & 8185 \\
Dominance_D (Indeks Dominansi) & 0,07215 & 0,07447 \\
Shannon_H (Indeks Keanekaragaman Shannon) & 2,718 & 2,684 \\
Simpson_1-D (Resiprok Indeks Diversitas Simpson) & 0,9278 & 0,9255 \\
Evenness_e^H/S (Indeks keseragaman jenis) & 0,8419 & 0,8618 \\
\hline
\end{tabular}

Jumlah individu, kelimpahan plankton pada lokasi sampling yaitu $7887-8185$ ind/L. Hasil penelitian dengan jumlah kelimpahan plankton sebesar 69.904 ind/L atau kecil dari $10^{4}$ ind/L termasuk dalam kategori kesuburan sedang (Anggara et al., 2017). Kelimpahan plankton pada lokasi penelitian termasuk dalam kategiri kesuburan sedang. Keanekaragaman plankton stasiun $\mathrm{Po}$ dan $\mathrm{Pa}$ dengan nilai indeks 2,718 dan 2,684 termasuk pada kondisi sedang atau komunitasnya moderat. Kriteria kualitas airnya 
berdasarkan indeks keanekaragaman Shannon-Wiener menurut Wilhm (1975) dan Lee et al., (1975) dalam Ferianita \& Fachrul (2007) termasuk setengah tercemar karena berkisar antara 1-3. Menurut Oktavia et al., (2015), faktor abiotik seperti Dissolved Oxygen (DO), Biological Oxygen Demand (BOD), pH, suhu dan kecerahan berpengaruh terhadap tinggi rendahnya keanekaragaman plankton.

Keseragaman plankton pada stasiun Po 0, 8419 dan stasiun $\mathrm{Pa}$ 0, 8618 pada kategori stabil. Sedangkan hasil analisis Indeks domonasi $(D=0,07)$ tidak didominasi jenis tertentu. Menurut Ana et al., (2013) Indeks Keseragaman diperoleh rata-rata untuk sampling pada waktu pasang dan surut dengan nilai yang sama yaitu 0, 56. Indeks Dominansi pada saat pasang dan surut juga mempunyai nilai yang sama, yaitu rata-rata 0,44 pada lokasi pengambilan sampel di Perairan Desa Mangunharjo. Kemudian Paramudhita et al., (2018) untuk indeks keseragaman zooplankton yang diperoleh berkisar antara 0,44-0,98 dan dikategorikan keseragaman sedang, dan untuk indeks dominansi diperoleh nilai berkisar antara 0,02-0,98 dan dikategorikan tidak ada genus yang mendominasi di Perairan Mangunharjo, terlihat bahwa pada penelitian ini mengindikasi dengan adanya perbedaan waktu dan metode pengambilan sampel yang berbeda juga hasilnya berbeda.

Kriteria kualitas airnya berdasarkan indeks keanekaragaman Shannon-Wiener menurut Wilhm, 1975 dan Lee et al., 1975 dalam Ferianita \& Fachrul (2007) termasuk setengah tercemar karena berkisar antara 1-3. Berdasarkan Indeks Diversitas Simpson maka tingkat pencemaran perairan Odum (1993) hasil penelitian adalah 0,9278 pada lokasi penelitian ( $\mathrm{Po}$ ) dan 0,9255 pada $\mathrm{Pa}$, dengan nilai ID > 0,8 maka termasuk tercemar ringan. .Fitoplankton merupakan produsen primer yang mampu merubah khlorofil menjadi senyawa organik yang kaya energi melalui proses fotosintesa.

\section{Kualitas Air}

Hasil analisis kualitas air pada kolam pasca tambang batubara seperti oksigen terlarut, $\mathrm{pH}, \mathrm{NO}_{2}, \mathrm{NH}_{3}$ dan $\mathrm{H}_{2} \mathrm{~S}$ berfluktuasi (Pagoray \& Ghitarina, 2016). Setelah dilakukan fitoremediasi terhadap perairan tersebut hasilnya menunjukkan bahwa proses fitoremediasi mampu memperbaiki kualitas air (Pagoray \& Ghitarina, 2020). Kualitas air yang diamati selama proses pengambilan sampel plankton berupa suhu, oksigen terlarut, $\mathrm{pH}$ dan amonaik. Suhu air pada kolam pasca tambang berada pada kisaran $29,0{ }^{\circ} \mathrm{C}-30,2{ }^{\circ} \mathrm{C}$. Kisaran suhu ini masih memenuhi standar baku mutu yang dipersyaratkan. Kisaran $\mathrm{pH}$ air pada titik sampling di kolam pasca tambang batubara berkisar antara 6.78-7.20, dimana kisaran ini masih memenuhi standard baku mutu yang dipersyaratkan. Kisaran pH yang terukur pada kolam pasca tambang batubara masih pada kisaran yang layak untuk kehidupan biota perairan, termasuk phytoplankton. Sofarini (2012) menyatakan bahwa nilai $\mathrm{pH}$ rata-rata 7,44 dapat mendukung kehidupan ikan dan jasad makanannya (fitoplankton). 
Hasil pengukuran oksigen terlarut pada kolam pasca tambang batubara berada pada kisaran 4,8-5,2 mg/l. Sofarini (2012) menyatakan bahwa kandungan oksigen yang berkisar antara 6.4-7.1 mg/l dengan rerata $6.86 \mathrm{mg} / \mathrm{l}$. termasuk kategori yang layak untuk kehidupan fitopalnkton. Hasil pengukuran $\mathrm{NH}_{3}$ pada lokasi sampling berada pada kisaran 0,12 - 0,17 mg/l. Menurut Sawyer dan McMarty, 1978 dalam Effendi (2000) kadar ammonia bebas apabila lebih besar dari $0,2 \mathrm{mg} / \mathrm{l}$ bersifat toksis bagi beberapa jenis ikan. Pada lokasi sampling kandungan ammonia melebihi standar sehingga apabila perairan tersebut akan digunakan untuk usaha budidaya maka perlu penanganan terhadap kadar ammonia yang melebihi standar.

Hasil pengukuran $\mathrm{NO}_{2}$ pada lokasi sampling yaitu $0,002 \mathrm{mg} / \mathrm{l}$. Nilai ini jika dibandingkan dengan standar baku mutu Perda Provinsi Kaltim No. 02 Tahun 2011 Lampiran V tentang Pengelolaan Kualitas Air dan Pengendalian Pencemaran Air nilai 0,06 mg/l. Nilai NO2 pada lokasi sampling masih di bawah standar. Hasil pengukuran H2S di lokasi sampling nihil (tidak terdeteksi).

\section{$4 \quad$ Kesimpulan}

Kesimpulan dari penelitian menunjukkan bahwa pada kolam pasca tambang batubara di Loa Bahu jumlah phytoplankton 3039- 3379 ind/L, zooplankton 4508-5146 ind/L, termasuk kategori kesuburan sedang. Phytoplankton di dominasi oleh Chlorophycea mencerminkan kualitas air bersih. Indeks keanekaragaman plankton 2,718-2,684, termasuk kategori sedang, keseragaman 0,8419-0,8618, termasuk kategori stabil. Hasil analisis kualitas air seperi suhu, oksigen terlarut, $\mathrm{pH}, \mathrm{NO}_{2}, \mathrm{H}_{2} \mathrm{~S}$ masih layak untuk budidaya sedangkan untuk $\mathrm{NH}_{3}$ melebihi standar.

\section{Daftar Pustaka}

Ana, D. L., Endrawati, H., \& Santosa, G. W. (2013). Struktur Komunitas Zooplankton di Perairan Desa Mangunharjo Kecamatan Tugu Semarang. Journal of Marine Research, 2(3), 197-204.

Anggara, A. P., Kartijono, N. E., \& Bodijantoro, P. M. H. (2017). Keanekaragaman Plankton di Kawasan Cagar Alam Tlogo Dringo, Dataran Tinggi Dieng, Jawa Tengah. Jurnal MIPA, 40(2), 74-79.

Effendi, H. (2000). Telaahan Kualitas Air Bagi Pengelolaan Sumberdaya dan Lingkungan Perairan. Jurusan Manajemen Sumberdaya Perairan, Fakultas Perikanan dan IImu Kelautan Institut Pertanian Bogor.

Ferianita, \& Fachrul, M. (2007). Metode Sampling Bioekologi. Jakarta: PT. Bumi Aksara.

Komarawidjaja, W. (2011). Analisis Indeks Kualitas Air Lingkungan Pertambangan Batubara PT KPC Subdas Sangatta Kalimantan Timur. Jurnal Teknologi Lingkungan, 12(2), 225-231. https://doi.org/10.29122/jtl.v12i2.1254 
Maidie, A., Udayana, D., Isriansyah, Almady, I. F., Susanto, A., Sukarti, K., ... Tular. (2010). Pemanfaatan Kolam Pengendap Tambang Batubara Untuk Budidaya Ikan Lokal Dalam Keramba. Jurnal Riset Akuakultur, 5(3), 437-448. https://doi.org/10.15578/jra.5.3.2010.437-448

Marganingrum, D., \& Noviardi, R. (2009). Pencemaran Air dan Tanah di Kawasan Pertambangan Batubara di PT. Berau Coal, Kalimantan Timur. Riset Geologi Dan Pertambangan, 20(1), 11-20.

Odum, E. P. (1993). Dasar-Dasar Ekologi Edisi Ketiga Alih Bahasa: Samingan, T. Yogyakarta: Gadjah Mada University Press.

Oktavia, N., Purnomo, T., \& Lisdiana, L. (2015). Keanekaragaman Plankton dan Kualitas Air Kali Surabaya. LenteraBio, 4(1), 103-107.

Pagoray, H., \& Ghitarina. (2016). Karakteristik Air Kolam Pasca Tambang Batubara yang Dimanfaatkan untuk Budidaya Perairan. Ziraa'ah Majalah IImiah Pertanian, 41(2), 276-284.

Pagoray, H., \& Ghitarina. (2020). The Use of Aqatic Plants as Organic Absorbent in Coal Mining Void Use for Aquacultute. AACL Bioflux, 13(2), 857-864.

Pagoray, H., Ghitarina, Maidie, A., Udayana, D., \& Zuraida, I. (2014). Pemanfaatan Lahan Bekas Penambangan Batubara Untuk Usaha Budidaya Ikan Yang Berkelanjutan. Jurnal Dinamika Pertanian, 29(2), 191-198.

Pagoray, H., Ghitarina, \& Udayana, D. (2015). Kualitas Plankton Pada Kolam Pasca Tambang Batu Bara Yang Dimanfaatkan Untuk Budidaya Perairan. Ziraa'ah Majalah IImiah Pertanian, 40(2), 108-113.

Paramudhita, W., Endrawati, H., \& Azizah, R. (2018). Struktur Komunitas Zooplankton Di Perairan Desa Mangunharjo Kecamatan Tugu Semarang. Buletin Oseanografi Marina, 7(2), 113-120.

Sofarini, D. (2012). Keradaan dan Kelimpahan Fitoplankton Sebagai Salah Satu Indikator Kesuburan Lingkungan Perairan di Waduk Riam Kanan. Enviro Scienteae, 8, 3034.

Wahyudi, T., Ghitarina, \& Sari, L. I. (2010). Studi Logam Berat pada Plankton di Kolam Pasca Penambangan PT. Banpu Kitadin Desa Kertabuana Kecamatan Tenggarong Seberang Kabupaten Kutai Kertanegara. Aquarin, 1(2), 64-69. 